\title{
Multivariate Analysis: Use of Doehlert Design (DD) for Optimization of a Simple Sample Preparation Procedure for the Determination of Inorganic Constituents in Cocoa Beans Employing Microwave Acid Digestion and ICP OES
}

\author{
Raimundo R. Gamela, ${ }^{a}$ Vinicius C. Costa,${ }^{b}$ Matheus L. de Mello, ${ }^{a}$ Julia C. Romero, ${ }^{c}$ \\ Fábio A. C. Amorim ${ }^{\circledR c, d}$ and Edenir R. Pereira-Filho ${ }^{\circledR *, a}$ \\ ${ }^{a}$ Grupo de Análise Instrumental Aplicada (GAIA), Departamento de Química, \\ Universidade Federal de São Carlos (UFSCar), 13560-270 São Carlos-SP, Brazil \\ ${ }^{b}$ Laboratório de Toxicologia e Análise de Drogas (LATF), Universidade Federal de Alfenas (Unifal), \\ 37130-000 Alfenas-MG, Brazil \\ 'Departamento de Ciências Extas e Tecnológicas, Universidade Estadual de Santa Cruz, \\ 4562-900 Ilhéus-BA, Brazil \\ ${ }^{d}$ Instituto Nacional de Energia e Ciências Ambientais e Tecnologia, Universidade Federal da Bahia, \\ 40170-115 Salvador-BA, Brazil
}

\begin{abstract}
This study presents a microwave-assisted procedure for sample preparation of cocoa beans using diluted $\mathrm{HNO}_{3}$ with $\mathrm{H}_{2} \mathrm{O}_{2}$ for the determination of $\mathrm{Ba}, \mathrm{Ca}, \mathrm{Cu}, \mathrm{K}, \mathrm{Mg}, \mathrm{Mn}, \mathrm{P}, \mathrm{S}, \mathrm{Sr}$ and $\mathrm{Zn}$ by inductively coupled plasma optical emission spectrometry (ICP OES). Doehlert modified design was used for optimization of experimental condition, and the volume of $\mathrm{H}_{2} \mathrm{O}_{2}(0,0.5,1.75$ and $3 \mathrm{~mL})$ and concentration of $\mathrm{HNO}_{3}\left(0.5,3.75\right.$ and $\left.7 \mathrm{~mol} \mathrm{~L}^{-1}\right)$ were evaluated. The best experimental conditions were chosen considering lower residual acidity (RA), lower dissolved organic carbon (DOC) and the acceptable trueness range (80-120\%), were $5 \mathrm{~mL}$ of $3.75 \mathrm{~mol} \mathrm{~L}^{-1} \mathrm{HNO}_{3}$ and $1.75 \mathrm{~mL}$ of $30 \% \mathrm{v} \mathrm{v} \mathrm{v}^{-1} \mathrm{H}_{2} \mathrm{O}_{2}$. The procedure was validate using certified reference materials (CRMs), digested using the optimized conditions. The proposed procedure was applied in twelve samples of cocoa beans, and the concentrations ( $\mathrm{mg} \mathrm{kg}^{-1}$ ) ranged from: 7.6-27 $(\mathrm{Ba}), 520-1955(\mathrm{Ca}), 11-26(\mathrm{Cu})$, 6212-10855 (K), 1677-2516 (Mg), 13-29 (Mn), 4679-6104 (P), 1499-1898 (S), 7-32 (Sr) and 34-46 ( $\mathrm{Zn})$. A Pearson correlation plot was proposed to evaluate the correlation between elements, revealing high correlations between $\mathrm{Mg}$ and $\mathrm{K} ; \mathrm{K}$ and $\mathrm{P} ; \mathrm{Cu}$ and $\mathrm{Mn} ; \mathrm{Cu}$ and $\mathrm{Zn} ; \mathrm{Cu}$ and $\mathrm{S}$.
\end{abstract}

Keywords: Doehlert design, microwave-assisted digestion, diluted acid, cocoa bean from southern of Bahia

\section{Introduction}

According to the International Cocoa Organization (ICO), the southern America region is the second major producer worldwide of cocoa bean (Theobroma cacao L.), with approximately $18 \%$ of the total. ${ }^{1,2}$ Currently, Brazil is the seventh largest producer of cocoa beans with approximately 200 thousand tons per year. ${ }^{1,2}$ In this scenario, the southern region of Bahia State is responsible for the majority of the production of cocoa bean in Brazil. ${ }^{1,2}$ However, despite the significant contribution of this region in the production of cocoa bean, the data about the chemical

*e-mail: erpf@ufscar.br composition of these samples are still insufficient or even absent in the literature.

It is reported in the scientific literature that the cocoa bean and its derivates have high levels of bioactive natural constituents (methylxanthines and phenolic compounds) and antioxidants that are beneficial compounds for human health. ${ }^{3-6}$ These compounds minimize the harmful effects caused by free radicals in the human body. In addition, it contributes to the reduction of cardiovascular disease and cancer risk. ${ }^{7,8}$ Cocoa bean and its derivatives, are also an important source of nutrients, such as $\mathrm{Ca}, \mathrm{Cu}, \mathrm{K}, \mathrm{Mg}$, Mn and P. ${ }^{9,10}$ However, some studies ${ }^{11-14}$ also reported the presence of potentially toxic elements, such as As, Ba, Cd, $\mathrm{Cr}, \mathrm{Ni}, \mathrm{Pb}$ and $\mathrm{Sb}$. Therefore, the elemental composition 
of cocoa beans should be monitored constantly in order to determine its chemical elements constituents.

Commonly, the determination of nutrients and potentially toxic elements in cocoa beans and its derivatives are performed by different analytical techniques, such as graphite furnace atomic absorption spectrometry (GF AAS), inductively coupled plasma optical emission spectrometry (ICP OES) and inductively coupled plasma mass spectrometry (ICP-MS) $)^{9-14}$ Nonetheless, these techniques are susceptible to severe matrix effects, which may influence the precision and accuracy of the analysis. These effects may be more severe in cocoa beans and its derivatives, due to peculiar characteristics of the matrix, as high fat content. ${ }^{6}$

One possible strategy to overcome matrix effects problems is the development of an efficient sample preparation method. ${ }^{15}$ In this sense, microwave-assisted digestion with closed vessels using dilute nitric acid $\left(\mathrm{HNO}_{3}\right)$ has been employed as an effective strategy for decomposition of complex samples, i.e., that contain high quantities of fats and oils, with similar results to those obtained after decomposition with concentrated acids. ${ }^{16-19}$ In addition, the use of dilute $\mathrm{HNO}_{3}$ presents some advantages, such as reduced analytical blank signal, which is correlated to lower limits of detection. Moreover, generates less aggressive waste, following green chemistry principles. ${ }^{20}$

In recent years, multivariate tools have been widely applied in analytical chemistry for the optimization of sample preparation methods of food samples. ${ }^{10,21-24}$ Doehlert design (DD) is an chemometric tool mostly used in analytical chemistry, and present advantages over others for response surface methodology (RSM), allowing: (i) estimate the parameters of the quadratic model, (ii) building of sequential designs, (iii) detection of lack of fit of the model, and (iv) use of blocks. ${ }^{25,26}$

In this study, a microwave-assisted digestion procedure using dilute $\mathrm{HNO}_{3}$ and $\mathrm{H}_{2} \mathrm{O}_{2}$ were used for multi-elemental determination of $\mathrm{Ba}, \mathrm{Ca}, \mathrm{Cu}, \mathrm{K}, \mathrm{Mg}, \mathrm{Mn}, \mathrm{P}, \mathrm{S}, \mathrm{Sr}$ and $\mathrm{Zn}$ in cocoa beans samples produced in Bahia. Additionally, the variables evaluated in the microwave-assisted digestion procedure were optimized using DD. Therefore, this study is devoted to development of a simple, fast and green sample preparation procedure for evaluation of the elemental composition of cocoa beans.

\section{Experimental}

Instrumentation

The determination of $\mathrm{Ba}, \mathrm{Ca}, \mathrm{Cu}, \mathrm{K}, \mathrm{Mg}, \mathrm{Mn}, \mathrm{P}, \mathrm{S}, \mathrm{Sr}$ and $\mathrm{Zn}$ was carried out using an inductively coupled plasma optical emission spectrometer (ICP OES) iCAP 7000 (Thermo Fisher, Madison, WI, USA). The measurements were performed using argon gas 99.999\% (White MartinsPraxair, Sertãozinho, SP, Brazil), utilizing both axial and radial viewing modes. The instrumental conditions and the emission lines used are shown in Table 1.

The sample decomposition was performed using a single reaction chamber oven (UltraWave $^{\mathrm{TM}}$, Milstone, Sorisole, Italy). Before digestion process, a volume of $150 \mathrm{~mL}$ of water and $5.0 \mathrm{~mL}$ of concentrated $\mathrm{HNO}_{3}$ were added into the single reaction chamber, which was pressurized with nitrogen gas (99.9\%, White Martins-Praxair, Sertãozinho, Brazil) until 40 bar.

Table 1. Instrumental parameters for ICP OES determinations

\begin{tabular}{lc}
\hline Parameter & ICP OES \\
\hline Radio frequency applied power / $\mathrm{kW}$ & 1.2 \\
Plasma gas flow rate / $\left(\mathrm{L} \mathrm{min}^{-1}\right)$ & 12.0 \\
Auxiliary gas flow rate / $\left(\mathrm{L} \mathrm{min}^{-1}\right)$ & 0.5 \\
Nebulizer gas flow rate / $\left(\mathrm{L} \mathrm{min}^{-1}\right)$ & 0.50 \\
\hline Analyte & Emission line, $\lambda / \mathrm{nm}$ \\
\hline $\mathrm{Ba}$ & 455.403 (II) \\
$\mathrm{Ca}$ & 393.366 (II) \\
$\mathrm{Cu}$ & 324.754 (I) \\
$\mathrm{K}$ & 766.490 (I) \\
$\mathrm{Mg}$ & 280.270 (II) \\
$\mathrm{Mn}$ & 259.373 (II) \\
$\mathrm{P}$ & 177.495 (I) \\
$\mathrm{S}$ & 182.034 (I) \\
$\mathrm{Sr}$ & 421.552 (II) \\
$\mathrm{Zn}$ & 213.856 (I) \\
\hline $\mathrm{I}$
\end{tabular}

I: atomic emission line, II: ionic emission line. ICP OES: inductively coupled plasma optical emission spectrometry.

\section{Standards, reagents and samples}

Analytical-grade reagents and deionized water (Milli-Q system, 18.2 M $\Omega \mathrm{cm}$, Millipore, Bedford, MA, USA) were used to prepare all solutions and standards. All glassware and vessels were soaked in a $10 \% \mathrm{v} \mathrm{v}^{-1} \mathrm{HNO}_{3}$ (Synth, Diadema, SP, Brazil) solution during $24 \mathrm{~h}$. After that, a rinsing step with deionized water was performed, and the materials were left to dry in a clean hood before use. The multielementar solutions used for external calibration were prepared from dilution of $1000 \mathrm{mg} \mathrm{L}^{-1}$ of $\mathrm{Ba}, \mathrm{Ca}, \mathrm{Cu}$, $\mathrm{K}, \mathrm{Mg}, \mathrm{Mn}, \mathrm{P}, \mathrm{S}, \mathrm{Sr}$ and $\mathrm{Zn}$ standard solutions (Qhemis, São Paulo, SP, Brazil) using dilute $\mathrm{HNO}_{3}$, i.e., $1 \% \mathrm{v} \mathrm{v}^{-1}$ (Synth, Diadema, SP, Brazil), previously purified using a 
sub-boiling distillation system Distillacid ${ }^{\mathrm{TM}}$ BSB-939-IR (Berghof, Eningen, Germany).

A total of twelve cocoa bean samples coded as S1 to S12 were obtained in an area of the Cocoa Research Center (CEPEC), an entity linked to the Executive Committee of the Cacao Plan (CEPLAC) of the Brazilian Ministry of Agriculture, Livestock and Supply (MAPA) localized in Bahia State. The samples were dried and grinded using a mortar and pestle to reduce the particle size and was not necessary to mash before digestion. In the case of fat content, the acquired samples did not present an enough quantity that could affect the process of sample preparation and further determination of inorganic constituents in cocoa beans.

In addition, four certified reference materials (CRMs) of baking chocolate (NIST 2384), apple leaves (NIST 1515), spinach leaves (NIST 1570a), and whole milk powder (NIST 8435), all from National Institute of Standard and Technology (Gaithersburg, MD, USA), were used to evaluate the efficiency of sample preparation method with diluted $\mathrm{HNO}_{3}$ and $\mathrm{H}_{2} \mathrm{O}_{2}$.

\section{Multivariate optimization of the digestion procedure}

The optimization of the digestion process for the sample preparation was performed using a Doehlert modified design. To carry out the optimization step, one sample of cocoa bean was chosen; moreover, some variables were evaluated, such as $\mathrm{HNO}_{3}$ concentration in three levels $\left(0.5,3.75\right.$ and $\left.7 \mathrm{~mol} \mathrm{~L}^{-1}\right)$, and the volume of $\mathrm{H}_{2} \mathrm{O}_{2}$ in four levels $(0,0.5,1.75$ and $3 \mathrm{~mL})$, as depicted in Table 2. For this, a total of 14 experiments were performed including 3 replicates at the central point in order to evaluate the experimental error. All data organization and calculations were performed using MATLAB 2018a. ${ }^{27}$

The optimal conditions for all elements were chosen considering the acceptable trueness (in percentage) calculated from the proposed method and the reference method using concentrated $\mathrm{HNO}_{3}$. Moreover, lower residual acidity and dissolved organic carbon were evaluated. In this sense, the multi-response optimization proposed by Candioti et al..$^{28}$ was taken in account, i.e., the criteria was to obtain trueness (in percentage) between 80 and $120 \%$ of each analyte and minimize both the residual acidity (RA, in $\% \mathrm{v} \mathrm{v}^{-1}$ ) and dissolved organic carbon (DOC, in $\mathrm{mg} \mathrm{L}^{-1}$ ). RA was calculated after titration of digested solutions with standardized $\mathrm{NaOH}$ solution. DOC was evaluated after the determination of $\mathrm{C}$ in the digested samples employing ICP OES. Oxalic acid was utilized to build the calibration curve for $\mathrm{C}$ determinations.

\section{Microwave-assisted sample preparation}

A mass of $200 \mathrm{mg}$ of cocoa beans was directly weighed in perfluoroalkoxy alkanes (PFA) vessels and, $5 \mathrm{~mL}$ of $3.75 \mathrm{~mol} \mathrm{~L}^{-1} \mathrm{HNO}_{3}$ and $1.75 \mathrm{~mL}$ of $30 \% \mathrm{v} \mathrm{v} \mathrm{v}^{-1} \mathrm{H}_{2} \mathrm{O}_{2}$ were added. The samples were submitted to the following heating program (temperature in ${ }^{\circ} \mathrm{C} / \mathrm{ramp}$ in min/hold in min): (i) $180 / 5 / 5$; (ii) $210 / 5 / 10$; (iii) $230 / 5 / 10$, and the limit

Table 2. Matrix of DD and results (trueness, RA, dissolved organic carbon and overall desirability, OD) for the optimization of sample preparation

\begin{tabular}{|c|c|c|c|c|c|c|c|c|c|c|c|c|c|c|c|}
\hline \multirow[b]{2}{*}{ Exp } & \multicolumn{2}{|c|}{ Variable } & \multicolumn{10}{|c|}{ Trueness / \% } & \multirow[b]{2}{*}{$\begin{array}{c}-\mathrm{RA} / \\
\left(\% \mathrm{~V} \mathrm{~V}^{-1}\right)\end{array}$} & \multirow[b]{2}{*}{$\begin{array}{c}\text { DOC / } \\
\left(\mathrm{mg} \mathrm{L}^{-1}\right)\end{array}$} & \multirow[b]{2}{*}{ OD } \\
\hline & $\begin{array}{c}\mathrm{H}_{2} \mathrm{O}_{2} / \\
\mathrm{mL}\end{array}$ & $\begin{array}{c}\mathrm{HNO}_{3} / \\
\left(\mathrm{mol} \mathrm{L}^{-1}\right)\end{array}$ & $\mathrm{Ca}$ & K & $\mathrm{Mg}$ & $\mathrm{P}$ & $\mathrm{S}$ & Mn & $\mathrm{Zn}$ & $\mathrm{Sr}$ & $\mathrm{Cu}$ & $\mathrm{Ba}$ & & & \\
\hline 1 & 1.75 & 3.75 & 129 & 135 & 116 & 91 & 111 & 98 & 100 & 24 & 69 & 36 & 3.45 & 384 & 0.6 \\
\hline 2 & 1.75 & 3.75 & 119 & 118 & 108 & 100 & 111 & 111 & 104 & 94 & 101 & 81 & 3.45 & 247 & 1.0 \\
\hline 3 & 1.75 & 3.75 & 113 & 120 & 107 & 86 & 107 & 121 & 99 & 94 & 93 & 81 & 3.45 & 459 & 0.9 \\
\hline 4 & 0.5 & 3.75 & 113 & 119 & 106 & 89 & 106 & 124 & 97 & 94 & 41 & 80 & 2.51 & 461 & 0.9 \\
\hline 5 & 3 & 3.75 & 128 & 129 & 113 & 91 & 110 & 123 & 102 & 102 & 96 & 88 & 4.39 & 683 & 0.9 \\
\hline 6 & 0.5 & 7 & 108 & 110 & 103 & 86 & 103 & 164 & 97 & 91 & 84 & 80 & 5.65 & 266 & 0.8 \\
\hline 7 & 1.75 & 7 & 118 & 118 & 107 & 89 & 105 & 92 & 99 & 97 & 89 & 84 & 7.06 & 624 & 0.9 \\
\hline 8 & 3 & 7 & 110 & 113 & 102 & 86 & 101 & 89 & 94 & 93 & 84 & 81 & 7.53 & 597 & 0.9 \\
\hline 9 & 0.5 & 0.5 & 114 & 127 & 111 & 96 & 104 & 126 & 84 & 101 & 81 & 91 & 0.20 & 655 & 0.9 \\
\hline 10 & 1.75 & 0.5 & 124 & 137 & 117 & 116 & 124 & 130 & 110 & 117 & 95 & 103 & 0.28 & 1246 & 0.8 \\
\hline 11 & 3 & 0.5 & 99 & 111 & 99 & 97 & 102 & 114 & 95 & 96 & 80 & 88 & 0.28 & 1660 & 0.9 \\
\hline 12 & 0 & 0.5 & 111 & 119 & 99 & 93 & 104 & 113 & 90 & 88 & 48 & 66 & 0.09 & 723 & 0.8 \\
\hline 13 & 0 & 3.75 & 105 & 108 & 100 & 89 & 104 & 117 & 99 & 88 & 87 & 76 & 2.20 & 490 & 1.0 \\
\hline 14 & 0 & 7 & 113 & 120 & 105 & 93 & 106 & 111 & 98 & 95 & 89 & 82 & 5.14 & 100 & 0.9 \\
\hline
\end{tabular}

Exp: experiment; RA: residual acidity; DOC: dissolved organic carbon. 
pressure of the digestion method was established as 110 bar. After that, the vessel content was transferred to volumetric flasks and the solution was diluted to $25 \mathrm{~mL}$ with ultrapure water before analysis.

\section{Results and Discussion}

\section{Optimization of microwave-assisted digestion}

A modified DD was used to adapt the codded and experimental conditions for practicality purpose, in order to optimize the best conditions of microwave-assisted digestion using diluted $\mathrm{HNO}_{3}$ and $\mathrm{H}_{2} \mathrm{O}_{2}$. Table 2 shows the performed experiments, as well as the trueness values obtained for $\mathrm{Ba}, \mathrm{Ca}, \mathrm{Cu}, \mathrm{K}, \mathrm{Mg}, \mathrm{Mn}, \mathrm{P}, \mathrm{S}, \mathrm{Sr}$ and $\mathrm{Zn}$. In addition, Table 2 displays the values of RA and DOC obtained for each experimental condition. The procedure was optimized using one sample of cocoa bean, and 14 experiments including three replicates in the central point (experiments 1, 2 and 3) were performed randomly.
To obtain a single experimental condition, overall desirability (OD, see Table 2) was calculated to ensure the compliance criteria using all responses simultaneously. The first step was to calculate the individual desirability (di) for each response, which implies that each response is converted to a value coded from 0 (undesired response) to 1 (desired response). Figure 1 shows a schematic diagram of individual desirability according to different criteria: trueness values (Figure 1a), RA $\left(\mathrm{v} \mathrm{v}^{-1}\right)$ (Figure 1b), and DOC $\left(\mathrm{mg} \mathrm{L}^{-1}\right)$ (Figure 1c). In this sense, the di $=1$ was attributed for the elements that presented the trueness from 80 to $120 \%$, RA below $2.5 \mathrm{v} \mathrm{v}^{-1}$ and DOC below $100 \mathrm{mg} \mathrm{L}^{-1}$. However, for the responses that present trueness values between 50 and 80 , the di was calculated using equation 1 .

$\mathrm{di}=\left(\frac{\mathrm{y}-\mathrm{L}}{\mathrm{T}-\mathrm{L}}\right)^{\mathrm{s}}$

The y corresponds to the response of the experiment, $\mathrm{L}$ (lower) and $\mathrm{T}$ (target) corresponds to 50 and $80 \%$,
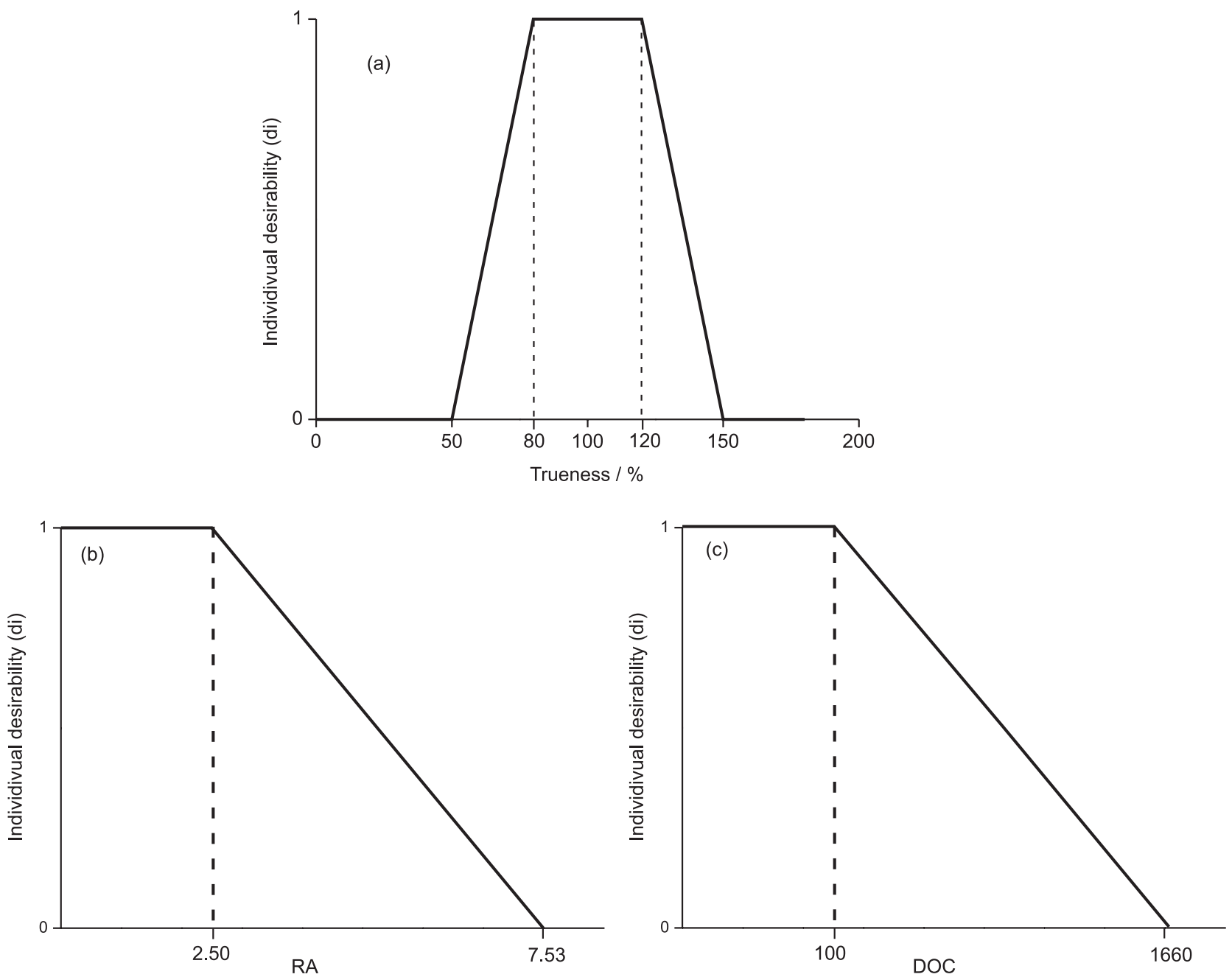

Figure 1. Schematic diagram of individual desirability calculation according to the following criteria: (a) trueness values, (b) RA, and (c) DOC. 
respectively, $\mathrm{s}$ is the weight used for calculation and in the specific case of this study was 1 .

On the other hand, the di for the responses that presents trueness values between 120 and $150 \%$, RA between 2.50 and $7.53 \mathrm{v} \mathrm{v}^{-1}$ and DOC between 100 and $1660 \mathrm{mg} \mathrm{L}^{-1}$ was calculated using equation 2 .

$\mathrm{di}=\left(\frac{\mathrm{U}-\mathrm{y}}{\mathrm{U}-\mathrm{T}}\right)^{\mathrm{t}}$

where the $\mathrm{y}$ is the response of the experiment, $\mathrm{U}$ (high value) equals to trueness of $150 \%$, RA $7.53 \mathrm{v} \mathrm{v}^{-1}$ and DOC $1660 \mathrm{mg} \mathrm{L}^{-1}$; $\mathrm{T}$ (target) corresponds to trueness of $120 \%$, RA $2.50 \mathrm{v} \mathrm{v}^{-1}$, DOC $100 \mathrm{mg} \mathrm{L}^{-1}$, and $\mathrm{t}$ is the weight used for calculation and in the specific case of this study was 1 . While $\mathrm{di}=0$ for responses that are outside of the acceptable trueness values, i.e., below of $50 \%$ and higher than $150 \%$, RA higher than $7.53 \mathrm{v} \mathrm{v}^{-1}$, and DOC higher than $1660 \mathrm{mg} \mathrm{L}^{-1}$.

After the di calculations for each response, the OD was calculated using the arithmetic mean of di of each experiment, as can be shown in Table 2. Arithmetic mean was used in this case in order to avoid 0 values for OD. After that, a mathematical model was generated and evaluated by analysis of variance (ANOVA) at 95\% of confidence level. Thus, the model obtained does not presented lack of fit because the ratio between the mean square of lack of fit (MSlof) and mean square of pure error (MSpe), the $F_{\text {calculated }}(0.194)$ was lower than $F_{\text {tabulated }}(19.3)$ at $95 \%$ confidence level. However, comparing the mean of square of regression (MSR) and mean of square of residue (MSres), the $F_{\text {calculated }}(0.118)$ should be higher than $F_{\text {tabulated }}$ (3.69). In this sense, it showed that the regression was not good enough, however, it does not affect the capability of the model in order to present a conclusion about the most convenient experimental condition. This design generated the OD calculated from equation 3 , and only the constant (b0) in bold was significant.

$\mathrm{OD}=\mathbf{0 . 8 5 4} \pm \mathbf{0 . 1 3 7}-0.002 \pm 0.104 \mathrm{v} 1+0.014 \pm$ $0.117 \mathrm{v} 2+0.070 \pm 0.179 \mathrm{v} 11-0.047 \pm 0.211 \mathrm{v} 22-$ $0.001 \pm 0.150 \mathrm{v} 1 \mathrm{v} 2$

v1 and v2 are linear coefficients for variables $1\left(\mathrm{H}_{2} \mathrm{O}_{2}\right)$ and $2\left(\mathrm{HNO}_{3}\right)$, respectively, $\mathrm{v} 11$ and $\mathrm{v} 22$ are quadratic coefficients for variables 1 and 2 , respectively and $\mathrm{v} 1 \mathrm{v} 2$ is the interaction coefficient.

As can be noted from equation 3 , the $\mathrm{HNO}_{3}$ concentration and volume of $\mathrm{H}_{2} \mathrm{O}_{2}$ were not significant. In this sense, any experimental domain can be used for the sample preparation procedure. In our specific case, the optimized values considered ideal and used for further sample preparation were $3.75 \mathrm{~mol} \mathrm{~L}^{-1}$ of $\mathrm{HNO}_{3}$ and $1.75 \mathrm{~mL}$ of $\mathrm{H}_{2} \mathrm{O}_{2}$ (central point), in addition showed satisfactory values of RA, $3.45 \% \mathrm{v} \mathrm{v}^{-1}$ and DOC $247 \mathrm{mg} \mathrm{L}^{-1}$.

It is important to emphasize that in some cases milder experimental conditions could be used; however, the decompositions were not efficient since the RA and/or DOC were high according to the results shown in Table 2 (experiments 4, 6, 9, and 10-13).

Analytical characteristics of the developed method and application

For the determination of $\mathrm{Ba}, \mathrm{Ca}, \mathrm{Cu}, \mathrm{K}, \mathrm{Mg}, \mathrm{Mn}, \mathrm{P}, \mathrm{S}$, $\mathrm{Sr}$ and $\mathrm{Zn}$ in cocoa beans, several analytical characteristics were evaluated. In this sense, the limit of detection (LOD) and quantification (LOQ) of the developed procedure were calculated considering three-fold and ten-fold standard deviation (SD) from ten consecutive measurements of the analytical blank. Table 3 shows the LOD and LOQ values for the developed procedure. It is possible to observe that these values are sufficiently lower, reflecting in good sensitivity of the method. Moreover, the precision was also evaluated considering the relative standard deviation (RSD, in percentage) for 5 authentic replicates digestions of a single sample using diluted $\mathrm{HNO}_{3}\left(3.75 \mathrm{~mol} \mathrm{~L}^{-1}\right)$ and $1.75 \mathrm{~mL}$ of $\mathrm{H}_{2} \mathrm{O}_{2}$, and the results are depicted in Table 3.

Table 3. Limits of detection (LOD) and quantification (LOQ), and relative standard deviation (RSD) obtained for proposed procedure

\begin{tabular}{lccc}
\hline \multirow{2}{*}{ Element } & \multicolumn{3}{c}{ Proposed procedure } \\
\cline { 2 - 4 } $\mathrm{Ba}$ & $\mathrm{LOD} /\left(\mathrm{mg} \mathrm{kg}^{-1}\right)$ & $\mathrm{LOQ} /\left(\mathrm{mg} \mathrm{kg}^{-1}\right)$ & $\mathrm{RSD} / \%$ \\
$\mathrm{Ca}$ & 0.1 & 0.4 & 6 \\
$\mathrm{Cu}$ & 5 & 17 & 8 \\
$\mathrm{~K}$ & 0.5 & 2 & 4 \\
$\mathrm{Mg}$ & 2 & 5 & 1 \\
$\mathrm{Mn}$ & 0.5 & 2 & 5 \\
$\mathrm{P}$ & 0.2 & 0.5 & 4 \\
$\mathrm{~S}$ & 196 & 653 & 2 \\
$\mathrm{Sr}$ & 13 & 43 & 1 \\
$\mathrm{Zn}$ & 0.05 & 0.2 & 7 \\
\hline
\end{tabular}

For the evaluation of the proposed procedure, four different CRMs, such as apple and spinach leaves, baking chocolate and whole milk powder were submitted to the optimized conditions described in previous sub-section "Optimization of microwave-assisted digestion", and the results are shown in Table 4. The results obtained using 
this procedure demonstrated that the concentration of the analytes in the majority of CRM are in agreement with certified values according to Student's $t$-test at $95 \%$ of confidence level. Some exceptions were observed and are marked as superscript "b". Nevertheless, in all cases presented acceptable trueness values (80-120\%), except for $\mathrm{S}$ in apple leaves. Moreover, the results obtained employing the total digestion of the samples with concentrated $\mathrm{HNO}_{3}$ and with proposed procedure were also compared using paired $t$-test at $95 \%$ of confidence level. The results showed that there is no significant difference between the reference method using concentrated $\mathrm{HNO}_{3}$ and the proposed procedure using diluted $\mathrm{HNO}_{3}$.

Therefore, the optimized conditions were used to determine the concentration levels of $\mathrm{Ba}, \mathrm{Ca}, \mathrm{Cu}, \mathrm{K}, \mathrm{Mg}$, $\mathrm{Mn}, \mathrm{P}, \mathrm{S}, \mathrm{Sr}$ and $\mathrm{Zn}$ in twelve different cocoa bean samples from Bahia, Brazil, and the results are shown in Table 5. The concentration values using the proposed method ranged from 7.6 to $27 \mathrm{mg} \mathrm{kg}^{-1}$ for Ba, 520 to $1955 \mathrm{mg} \mathrm{kg}^{-1}$ for $\mathrm{Ca}, 11$ to $26 \mathrm{mg} \mathrm{kg}^{-1}$ for $\mathrm{Cu}, 6212$ to $10855 \mathrm{mg} \mathrm{kg}^{-1}$ for $\mathrm{K}, 1677$ to $2516 \mathrm{mg} \mathrm{kg}^{-1}$ for $\mathrm{Mg}, 13$ to $29 \mathrm{mg} \mathrm{kg}^{-1}$ for $\mathrm{Mn}$, 4679 to $6104 \mathrm{mg} \mathrm{kg}^{-1}$ for P, 1499 to $1898 \mathrm{mg} \mathrm{kg}^{-1}$ for S, 7 to $32 \mathrm{mg} \mathrm{kg}^{-1}$ for $\mathrm{Sr}$ and 34 to $46 \mathrm{mg} \mathrm{kg}^{-1}$ for $\mathrm{Zn}$.

From the results, is possible to note that $\mathrm{Ca}, \mathrm{K}, \mathrm{Mg}, \mathrm{P}$ and $\mathrm{S}$ are major constituents in all samples, while $\mathrm{Ba}, \mathrm{Cu}, \mathrm{Mn}$, $\mathrm{Ni}, \mathrm{Sr}$ and $\mathrm{Zn}$ are found at lower levels. Due to nutritional reasons, the determination of chemical constituents in this type of sample is important, once cocoa bean samples are used as raw material for production of cocoa powder, chocolates and other products used in the human diet.
How the chemical elements determined by ICP OES are correlated in the samples?

In this section, we intend to evaluate the correlation among the elements and, at the same time explain why it occurs. For this purpose, the concentration values of the determined elements were organized in a matrix $\mathbf{X}(10 \times 12)$, where the columns and rows correspond to the elements (10 analytes) and their concentrations at the samples (12), respectively. After that, the data were subjected to an exploratory analysis employing the Pearson correlation coefficient (R). This procedure measures the linear correlation degree between the elements determined by ICP OES technique.

To explain the possible correlation in the samples, a Pearson correlation plot was generated. In addition, each value obtained from the correlation coefficients is related to specific color, i.e., the highest absolute value near to 1 indicates or reflects a higher intensity of linear relationship among elements.

Figure 2 shows the Pearson correlation plot used to correlate the elements in the sample. Blue and red color represents the low and high correlation between elements, respectively. In addition, the correlation of a determined element with itself is always equal to 1 .

As an example of this correlation, according to Figure 2, $\mathrm{Mg}$ and $\mathrm{K}$ are highly correlated in the samples, which means that, when the concentration of Mg increases, the concentration values of $\mathrm{K}$ also increases simultaneously. The same behavior can be observed for other chemical elements such as $\mathrm{K}$ and $\mathrm{P}, \mathrm{Cu}$ and $\mathrm{Mn}, \mathrm{Cu}$ and $\mathrm{Zn}$, and $\mathrm{Cu}$

Table 4. Concentration values of $\mathrm{Ca}, \mathrm{Cu}, \mathrm{Ba}, \mathrm{K}, \mathrm{Mg}, \mathrm{Mn}, \mathrm{P}, \mathrm{S}, \mathrm{Sr}$ and $\mathrm{Zn}$ obtained in certified reference materials using proposed procedure (mean \pm standard deviation, $\mathrm{n}=3$ and trueness)

\begin{tabular}{|c|c|c|c|c|c|c|c|c|}
\hline \multirow[b]{3}{*}{ Element ${ }^{-}$} & \multicolumn{8}{|c|}{ Concentration / $\left(\mathrm{mg} \mathrm{kg}^{-1}\right)$} \\
\hline & \multicolumn{2}{|c|}{ Baking chocolate (NIST 2384) } & \multicolumn{2}{|c|}{ Apple leaves (NIST 1515) } & \multicolumn{2}{|c|}{ Spinach leaves (NIST 1570a) } & \multicolumn{2}{|c|}{ Whole milk powder (NIST 8435) } \\
\hline & Certified value & $\begin{array}{l}\text { Proposed } \\
\text { procedure } \\
\text { (trueness) }\end{array}$ & Certified value & $\begin{array}{l}\text { Proposed } \\
\text { procedure } \\
\text { (trueness) }\end{array}$ & Certified value & $\begin{array}{l}\text { Proposed } \\
\text { procedure } \\
\text { (trueness) }\end{array}$ & Certified value & $\begin{array}{l}\text { Proposed } \\
\text { procedure } \\
\text { (trueness) }\end{array}$ \\
\hline $\mathrm{Ba}$ & a & - & $49 \pm 2$ & $48.8 \pm 0.2(100)$ & a & - & a & - \\
\hline $\mathrm{Ca}$ & $840 \pm 74$ & $865.9 \pm 0.2(103)^{\mathrm{b}}$ & $15250 \pm 100$ & $14147 \pm 126(93)^{\mathrm{b}}$ & $15270 \pm 410^{\mathrm{b}}$ & $14275 \pm 52(94)^{\mathrm{b}}$ & $9220 \pm 490$ & $9966 \pm 445(108)^{b}$ \\
\hline $\mathrm{Cu}$ & $24 \pm 1$ & $21.9 \pm 0.5(91)^{b}$ & $5.7 \pm 0.1$ & $5.1 \pm 0.5(90)$ & $12.2 \pm 0.6$ & $14 \pm 1(115)$ & $0.46 \pm 0.08$ & $0.42 \pm 0.02(91)$ \\
\hline K & $8650 \pm 400$ & $7120 \pm 17(82)^{\mathrm{b}}$ & $16080 \pm 210$ & $12821 \pm 198(80)^{\mathrm{b}}$ & $29030 \pm 520$ & $24053 \pm 760(82)^{b}$ & $13630 \pm 470$ & $10746 \pm 139(79)^{\mathrm{b}}$ \\
\hline $\mathrm{Mg}$ & $2610 \pm 120$ & $2624 \pm 101(101)$ & $2710 \pm 120$ & $2649 \pm 33(98)$ & a & - & $814 \pm 76$ & $835 \pm 3(103)^{\mathrm{b}}$ \\
\hline $\mathrm{Mn}$ & $21 \pm 1$ & $21.7 \pm 0.4(103)$ & $54 \pm 1$ & $46 \pm 3(85)^{\mathrm{b}}$ & $76 \pm 2$ & $75 \pm 5(99)$ & $0.17 \pm 0.05$ & $0.18 \pm 0.01(106)$ \\
\hline$P$ & $3330 \pm 210$ & $3333 \pm 32(100)$ & $1593 \pm 68$ & $1781 \pm 21(112)^{b}$ & $5180 \pm 110$ & $5059 \pm 153(98)$ & $7800 \pm 490$ & $7411 \pm 138(95)^{\mathrm{b}}$ \\
\hline $\mathrm{S}$ & a & - & $1800^{c}$ & $1279 \pm 72(71)$ & $4600^{c}$ & $4818 \pm 142(105)$ & $2650 \pm 350$ & $2346 \pm 56(86)^{b}$ \\
\hline $\mathrm{Sr}$ & a & - & $25 \pm 1$ & $24.9 \pm 0.3(100)$ & $55.6 \pm 0.8$ & $54.6 \pm 0.5(98)$ & $4.3 \pm 0.5$ & $4.3 \pm 0.1(100)$ \\
\hline $\mathrm{Zn}$ & $38 \pm 2$ & $37 \pm 1(97)$ & $12.4 \pm 0.5$ & $13.2 \pm 0.1(107)^{\mathrm{b}}$ & $82 \pm 3$ & $76 \pm 1(93)^{\mathrm{b}}$ & $28 \pm 3$ & $27 \pm 0.5(97)$ \\
\hline
\end{tabular}

aValue not informed; ${ }^{\text {th }}$ he obtained value was not statistically concordant with certified value using Student's $t$-test at $95 \%$ of confidence level; ${ }^{\text {informative }}$ value. 
Table 5. Comparison among the concentration values obtained using microwave digestion with proposed procedure and concentrated acid in the sample preparation for the determination of $\mathrm{Ca}, \mathrm{Cu}, \mathrm{Ba}, \mathrm{K}, \mathrm{Mg}, \mathrm{Mn}, \mathrm{P}, \mathrm{S}, \mathrm{Sr}$ and $\mathrm{Zn}$ in cocoa beans (mean \pm standard deviation, $\mathrm{n}=3$ and trueness)

\begin{tabular}{|c|c|c|c|c|c|c|c|c|c|c|c|}
\hline \multirow{2}{*}{ Sample } & \multirow{2}{*}{$\begin{array}{c}\text { Sample } \\
\text { preparation }\end{array}$} & \multicolumn{10}{|c|}{ Concentration / $\left(\mathrm{mg} \mathrm{kg}^{-1}\right)$} \\
\hline & & $\mathrm{Ba}$ & $\mathrm{Ca}$ & $\mathrm{Cu}$ & $\mathrm{K}$ & $\mathrm{Mg}$ & $\mathrm{Mn}$ & $\mathrm{P}$ & $S$ & $\mathrm{Sr}$ & $\mathrm{Zn}$ \\
\hline \multirow{2}{*}{ S1 } & $\begin{array}{l}\text { proposed } \\
\text { procedure }\end{array}$ & $25 \pm 1$ & $1125 \pm 22$ & $11.9 \pm 0.3$ & $9727 \pm 503$ & $2516 \pm 27$ & $21.5 \pm 0.6$ & $6100 \pm 284$ & $1546 \pm 22$ & $31.6 \pm 0.9$ & $41 \pm 1$ \\
\hline & $\begin{array}{c}\text { concentrated } \\
\text { acid } \\
\end{array}$ & $23.5 \pm 0.3$ & $1070 \pm 15$ & $11.60 \pm 0.06$ & $5030 \pm 68$ & $2589 \pm 7$ & $20.25 \pm 0.03$ & $8628 \pm 55$ & $1465 \pm 3$ & $29.27 \pm 0.05$ & $40 \pm 1$ \\
\hline \multirow{2}{*}{ S2 } & $\begin{array}{l}\text { proposed } \\
\text { procedure }\end{array}$ & $13.0 \pm 0.3$ & $520 \pm 13$ & $21.0 \pm 0.5$ & $7340 \pm 290$ & $2299 \pm 8$ & $22.6 \pm 0.3$ & $5029 \pm 122$ & $1712 \pm 13$ & $13.2 \pm 0.1$ & $43 \pm 10$ \\
\hline & $\begin{array}{c}\text { concentrated } \\
\text { acid }\end{array}$ & $12.0 \pm 0.3$ & $474 \pm 7$ & $18.1 \pm 0.8$ & $5663 \pm 95$ & $2219 \pm 77$ & $20.5 \pm 0.9$ & $5106 \pm 158$ & $1457 \pm 54$ & $12.0 \pm 0.2$ & $40.8 \pm 0.2$ \\
\hline \multirow{2}{*}{ S3 } & $\begin{array}{l}\text { proposed } \\
\text { procedure }\end{array}$ & $16.8 \pm 0.2$ & $690 \pm 30$ & $26 \pm 1$ & $9730 \pm 569$ & $2452 \pm 102$ & $29 \pm 1$ & $6104 \pm 210$ & $1681 \pm 33$ & $12.1 \pm 0.3$ & $43 \pm 1$ \\
\hline & $\begin{array}{c}\text { concentrated } \\
\text { acid }\end{array}$ & $13.6 \pm 0.4$ & $560 \pm 28$ & $20 \pm 1$ & $6929 \pm 25$ & $2133 \pm 104$ & $24 \pm 1$ & $6572 \pm 237$ & $1426 \pm 16$ & $9.5 \pm 0.3$ & $36.7 \pm 0.9$ \\
\hline \multirow{2}{*}{ S4 } & $\begin{array}{l}\text { proposed } \\
\text { procedure }\end{array}$ & $9.0 \pm 0.6$ & $694 \pm 52$ & $16.9 \pm 0.7$ & $8830 \pm 111$ & $2240 \pm 100$ & $15 \pm 1$ & $5219 \pm 125$ & $1637 \pm 13$ & $9 \pm 1$ & $45 \pm 1$ \\
\hline & $\begin{array}{c}\text { concentrated } \\
\text { acid } \\
\end{array}$ & $8.4 \pm 0.8$ & $618 \pm 8$ & $15.7 \pm 0.4$ & $6601 \pm 55$ & $2078 \pm 51$ & $12.6 \pm 0.3$ & $6806 \pm 33$ & $1513 \pm 11$ & $8.1 \pm 0.2$ & $42 \pm 1$ \\
\hline \multirow{2}{*}{ S5 } & $\begin{array}{l}\text { proposed } \\
\text { procedure }\end{array}$ & $10.6 \pm 0.3$ & $886 \pm 34$ & $15.5 \pm 0.4$ & $10855 \pm 284$ & $2406 \pm 16$ & $14.4 \pm 0.2$ & $5689 \pm 101$ & $1635 \pm 6$ & $12.0 \pm 0.3$ & $40.0 \pm 0.2$ \\
\hline & $\begin{array}{c}\text { concentrated } \\
\text { acid } \\
\end{array}$ & $10 \pm 1$ & $803 \pm 76$ & $15 \pm 2$ & $8815 \pm 600$ & $2394 \pm 215$ & $13.0 \pm 0.9$ & $5993 \pm 161$ & $1472 \pm 38$ & $11 \pm 1$ & $36 \pm 2$ \\
\hline \multirow{2}{*}{ S6 } & $\begin{array}{l}\text { proposed } \\
\text { procedure }\end{array}$ & $21.7 \pm 0.4$ & $921 \pm 42$ & $25 \pm 2$ & $10292 \pm 751$ & $2491 \pm 101$ & $24 \pm 2$ & $5892 \pm 449$ & $1898 \pm 66$ & $13.9 \pm 0.3$ & $45 \pm 3$ \\
\hline & $\begin{array}{c}\text { concentrated } \\
\text { acid }\end{array}$ & $20 \pm 2$ & $897 \pm 85$ & $23 \pm 2$ & $9228 \pm 168$ & $2557 \pm 239$ & $22 \pm 1$ & $8611 \pm 615$ & $1853 \pm 63$ & $13 \pm 1$ & $44 \pm 4$ \\
\hline \multirow{2}{*}{ S7 } & $\begin{array}{l}\text { proposed } \\
\text { procedure }\end{array}$ & $17.7 \pm 0.4$ & $840 \pm 17$ & $20.78 \pm 0.04$ & $49707 \pm 469$ & $2397 \pm 16$ & $26.5 \pm 0.4$ & $6101 \pm 311$ & $1711 \pm 51$ & $12.1 \pm 0.1$ & $44 \pm 0.6$ \\
\hline & $\begin{array}{c}\text { concentrated } \\
\text { acid } \\
\end{array}$ & $15.9 \pm 0.3$ & $791 \pm 50$ & $18.8 \pm 0.2$ & $8010 \pm 231$ & $2424 \pm 115$ & $25 \pm 1$ & $6404 \pm 387$ & $1482 \pm 15$ & $11.2 \pm 0.5$ & $40 \pm 2$ \\
\hline \multirow{2}{*}{ S8 } & $\begin{array}{l}\text { proposed } \\
\text { procedure }\end{array}$ & $12.2 \pm 0.5$ & $555 \pm 25$ & $20 \pm 1$ & $7909 \pm 687$ & $2010 \pm 103$ & $15.4 \pm 0.7$ & $4720 \pm 150$ & $1688 \pm 42$ & $7.4 \pm 0.5$ & $39 \pm 1$ \\
\hline & $\begin{array}{c}\text { concentrated } \\
\text { acid }\end{array}$ & $11.2 \pm 0.4$ & $517 \pm 10$ & $19.2 \pm 0.5$ & $7018 \pm 97$ & $1996 \pm 26$ & $14.59 \pm 0.07$ & $6183 \pm 10$ & $1614 \pm 11$ & $6.9 \pm 0.1$ & $36.3 \pm 0.7$ \\
\hline \multirow{2}{*}{ S9 } & $\begin{array}{l}\text { proposed } \\
\text { procedure }\end{array}$ & $25.2 \pm 0.4$ & $622 \pm 7$ & $15.3 \pm 0.3$ & $6212 \pm 245$ & $1677 \pm 27$ & $14.7 \pm 0.4$ & $4679 \pm 10$ & $1521 \pm 6$ & $15.6 \pm 0.2$ & $42.1 \pm 0.4$ \\
\hline & $\begin{array}{c}\text { concentrated } \\
\text { acid }\end{array}$ & $22 \pm 2$ & $540 \pm 47$ & $13 \pm 2$ & $4811 \pm 367$ & $1572 \pm 169$ & $13 \pm 2$ & $4800 \pm 404$ & $1293 \pm 85$ & $13 \pm 1$ & $38 \pm 3$ \\
\hline \multirow{2}{*}{ S10 } & $\begin{array}{l}\text { proposed } \\
\text { procedure }\end{array}$ & $27.0 \pm 0.4$ & $703 \pm 6$ & $18 \pm 1$ & $7403 \pm 123$ & $1967 \pm 17$ & $25 \pm 1$ & $5058 \pm 136$ & $1589 \pm 40$ & $13.1 \pm 0.2$ & $46 \pm 1$ \\
\hline & $\begin{array}{c}\text { concentrated } \\
\text { acid }\end{array}$ & $26 \pm 1$ & $678 \pm 46$ & $17 \pm 1$ & $6719 \pm 240$ & $2097 \pm 14$ & $25 \pm 1$ & $6366 \pm 111$ & $1428 \pm 70$ & $12.7 \pm 0.3$ & $44 \pm 3$ \\
\hline \multirow{2}{*}{ S11 } & $\begin{array}{l}\text { proposed } \\
\text { procedure }\end{array}$ & $7.6 \pm 0.2$ & $1955 \pm 284$ & $12.6 \pm 0.1$ & $9367 \pm 803$ & $2177 \pm 31$ & $13.1 \pm 0.2$ & $5755 \pm 240$ & $1545 \pm 24$ & $13 \pm 1$ & $34 \pm 2$ \\
\hline & $\begin{array}{c}\text { concentrated } \\
\text { acid } \\
\end{array}$ & $6.95 \pm 0.03$ & $1880 \pm 9$ & $11.60 \pm 0.01$ & $7576 \pm 65$ & $2206 \pm 4$ & $12.5 \pm 0.3$ & $6308 \pm 3$ & $1376 \pm 16$ & $9.4 \pm 0.1$ & $32.2 \pm 0.7$ \\
\hline \multirow{2}{*}{ S12 } & $\begin{array}{l}\text { proposed } \\
\text { procedure }\end{array}$ & $23 \pm 1$ & $584 \pm 11$ & $11.3 \pm 0.2$ & $7274 \pm 453$ & $1871 \pm 32$ & $15.1 \pm 0.2$ & $5261 \pm 276$ & $1499 \pm 4$ & $23 \pm 1$ & $33.6 \pm 0.2$ \\
\hline & $\begin{array}{c}\text { concentrated } \\
\text { acid }\end{array}$ & $20 \pm 3$ & $524 \pm 58$ & $10 \pm 2$ & $5798 \pm 380$ & $1932 \pm 225$ & $13 \pm 2$ & $5892 \pm 519$ & $1344 \pm 56$ & $20 \pm 2$ & $29 \pm 4$ \\
\hline
\end{tabular}

and $\mathrm{S}$ which presents high correlation and converge in or near of red color.

There was noticed an inversely correlation with elements $\mathrm{Ba}, \mathrm{Ca}, \mathrm{K}, \mathrm{S}$ and $\mathrm{Sr}$, i.e., when the concentration values of these elements increase, the concentration values of other elements decrease. However, the lower or higher correlation between elements in the samples can be related to the type of fertilizer used in the soil fortification.

A study performed by Jiao et al. ${ }^{29}$ related to the growth and nutrient response of flax and durum wheat to $\mathrm{P}$ and $\mathrm{Zn}$ 
fertilizers or mixture of them, shows how application of $\mathrm{P}$ and $\mathrm{Zn}$ fertilizers on the nutrient composition can affect the translocation of nutrients to the seed or grain.

The authors explain that, for example, $\mathrm{P}$ fertilizers enhanced $\mathrm{Fe}$ but reduced $\mathrm{Ca}$ and $\mathrm{S}$, although increased $\mathrm{K}$ translocation to the seed and grain. While $\mathrm{Zn}$ fertilizers had no effect on $\mathrm{K}$, enhanced $\mathrm{Ca}$, but decrease $\mathrm{S}$ and $\mathrm{Fe}$ in grain. Therefore, the results obtained in present study shows a similar tendency if we assumed that the production of these seeds were based on $\mathrm{P}$ and $\mathrm{Zn}$ fertilizers.

Therefore, it is well known that, in the cocoa beans production, $\mathrm{P}$ and $\mathrm{Zn}$ fertilizers have been used to fill the deficiencies of these elements in order to improve the soil fertility. As shown in Figure 2, for example, high content of $\mathrm{P}$ can enhance the $\mathrm{Mg}$ and $\mathrm{K}$ concentration, but also reduce $\mathrm{Ca}$ and $\mathrm{S}$ content; however, the high content of $\mathrm{Zn}$ fertilizers can prevent the absorption of $\mathrm{Ca}, \mathrm{K}$ and $\mathrm{P}$ content. Thus, the results showed in the Pearson correlation plot can be related to the type of fertilizers used and soil, moreover, also depends on the type of culture.

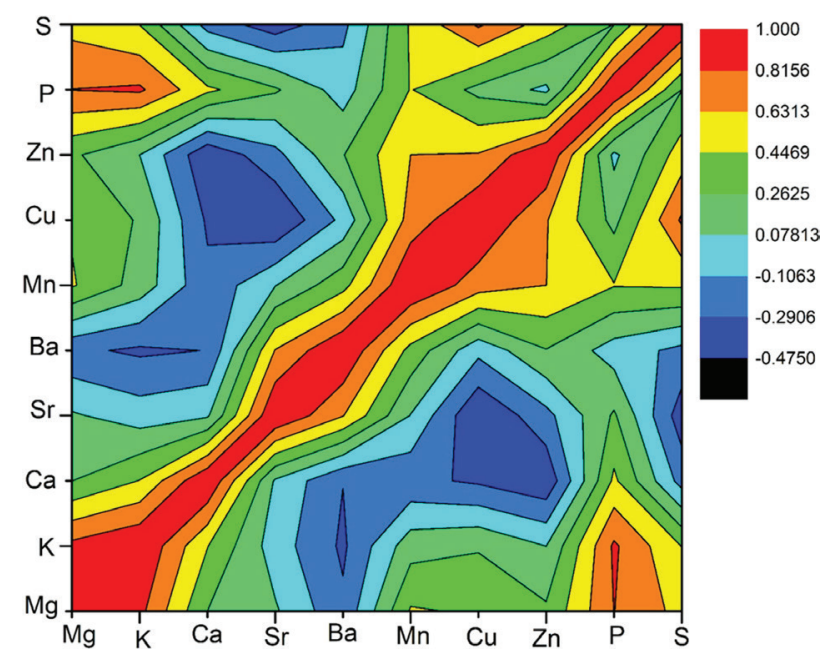

Figure 2. Pearson plot used to evaluate the correlation $(\mathrm{R})$ of the elements in the samples.

\section{Conclusions}

The use of DD for optimization of microwave-assisted digestion showed to be effective for sample preparation of cocoa beans for the determination of micro and macro nutrients using $3.75 \mathrm{~mol} \mathrm{~L}^{-1}$ of $\mathrm{HNO}_{3}$ (diluted) and $1.75 \mathrm{~mL}$ of $\mathrm{H}_{2} \mathrm{O}_{2}$. The proposed procedure showed the best results, where the trueness values are in the acceptable range. Moreover, combining multivariate optimization and other chemometric tools, was possible to evaluate the higher and lower correlation of the elements in the samples using Pearson correlation plot.

\section{Acknowledgments}

The authors acknowledge the financial support to CNPq/TWAS (158587/2017-0), CNPq (305637/2015-0 and 147727/2018-9) and FAPESP (2016/01513-0). This study was financed in part by CAPES-finance code 001 and by FAPESB.

\section{Author Contributions}

Raimundo R. Gamela was responsible for formal analysis, conceptualization; visualization; roles/writingoriginal draft; writing-review and editing; Vinicius C. Costa for formal analysis; visualization, roles/writingoriginal draft, writing-review and editing; Matheus L. de Mello for formal analysis, conceptualization, visualization, roles/writing-original draft; Julia C. Romero for formal analysis; Fábio A. C. Amorim for formal analysis; Edenir R. P. Filho for formal analysis, funding acquisition, project administration, resources, supervision, visualization, writing-review and editing.

\section{References}

1. International Cocoa Organization (ICO); Production-Latest Figures from the Quarterly Bulletin of Cocoa Statistics, available at http://www.icco.org/about-us/international-cocoaagreements/cat_view/30-related-documents/46-statisticsproduction.htm, accessed in June 2020.

2. World Cocoa Foundation (WCF); History of Cocoa; available at https://www.worldcocoafoundation.org/about-wcf/history/, accessed in June 2020.

3. Salger, M.; Stark, T. D.; Hofmann, T.; J. Agric. Food Chem. 2019, 67, 4311.

4. Febrianto, N. A.; Zhu, F.; J. Agric. Food Chem. 2019, 67, 9501.

5. Cambrai, A.; Marchioni, E.; Julien-David, D.; Marcic, C.; Food Anal. Methods 2017, 10, 1991.

6. Loureiro, G. A. H. A.; Araujo, Q. R.; Sodré, G. A.; Valle, R. R.; Sousa Jr., J. O.; Ramos, E. M. L. S.; Comerford, N. B.; Grierson, P. F.; Food Rev. Int. 2017, 33, 382.

7. Andújar, I.; Recio, M. C.; Giner, R. M.; Ríos, J. L.; Oxid. Med. Cell. Longevity 2012, 2012, 906252.

8. Cienfuegos-Jovelanos, E.; Quinones, M. M.; Muguerza, B.; Moulay, L.; Miguel, M.; Aleixandre, A.; J. Agric. Food Chem. 2009, 57, 6156.

9. Villa, J. E. L.; Pereira, C. D.; Cadore, S.; Microchem. J. 2015, 121, 199.

10. Costa, V. C.; Pinheiro, F. C.; Amorim, F. A. C.; Silva, E. G. P.; Pereira-Filho, E. R.; Microchem. J. 2019, 150, 104166.

11. Villa, J. E. L.; Peixoto, R. R. A.; Cadore, S.; J. Agric. Food Chem. 2014, 62, 8759. 
12. Dico, G. M. L.; Galvano, F.; Dugo, G.; D’ascenzi, C.; Macaluso, A.; Vella, A.; Giangrosso, G.; Cammilleri, G.; Ferrantelli, V.; Food Chem. 2018, 245, 1163.

13. Kruszewskia, B.; Obiedziński, M. W.; Kowalska, J.; J. Food Compos. Anal. 2018, 66, 127.

14. Mohamed, R.; Zainudin, B. H.; Yaakob, A. S.; Food Chem. 2020, 303, 125392

15. Flores, E. M. M.; Microwave-Assisted Sample Preparation for Trace Element Determination, $1^{\text {st }}$ ed.; Elsevier: Amsterdam, 2014.

16. Pinheiro, F. C.; Barros, A. I.; Nóbrega, J. A.; Anal. Chim. Acta 2019, $1065,1$.

17. Pinheiro, F. C.; Babos, D. V.; Barros, A. I.; Pereira-Filho, E. R.; Nóbrega, J. A.; J. Pharm. Biomed. Anal. 2019, 174, 471.

18. Santos, H. M.; Coutinho, J. P.; Amorim, F. A. C.; Lobo, I. P.; Moreira, L. S.; Nascimento, M. M.; de Jesus, R. M.; Food Chem. 2019, 273, 159 .

19. Rocha, D. L.; Batista, A. D.; Rocha, F. R. P.; Donati, G. L.; Nóbrega, J. A.; TrAC, Trends Anal. Chem. 2013, 45, 79.

20. Bendicho, C.; Lavilla, I.; Pena-Pereira, F.; Romero, V.; J. Anal. At. Spectrom. 2012, 27, 1831.

21. Costa, V. C.; Babos, D. V.; Gamela, R. R.; Amorim, F. A. C.; Pereira-Filho, E. R.; Food Anal. Methods 2020, 13, 145.
22. Amorim, F. A. C.; Costa, V. C.; Guedes, W. N.; de Sa, I. P.; dos Santos, M. C.; da Silva, E. G. P.; Lima, D. C.; Food Anal. Methods 2016, 9, 1719.

23. Costa, V. C.; Silva, E. G. P.; Lima, D. C.; Franco, M.; Jesus, R. M.; Bezerra, M. A.; Amorim, F. A. C.; J. Braz. Chem. Soc. 2018, 29, 1189.

24. Lima, D. C.; Guedes, W. N.; Costa, V. C.; Amorim, F. A. C.; J. Braz. Chem. Soc. 2018, 29, 1885.

25. Pereira, F. M. V.; Pereira-Filho, E. R.; Quim. Nova 2018, 41, 1061.

26. Ferreira, S. L. C.; Lemos, V. A.; Carvalho, V. S.; Silva, E. G. P.; Queiroz, A. F. S.; Felix, C. S. A.; Silva, D. L. F.; Dourado, G. B.; Oliveira, R. V.; Microchem. J. 2018, 140, 176.

27. MATLAB, version 2018a; Mathworks, Natick, MA, USA, 2018.

28. Candioti, L. V.; Zan, M. M.; Cámara, M. S.; Goicoechea, H. C.; Talanta 2014, 124, 123.

29. Jiao, Y.; Grant, C. A.; Baily, L. D.; Can. J. Plant Sci. 2007, 87, 461.

Submitted: March 1, 2020

Published onlie: June 9, 2020 